that interferometer work was in progress at Mt Wilson under Baade and Minkowski. Prof. Russell spoke concerning the great progress made, chiefly by Bowen, since the last I.A.U. meetings, in the elucidation of the spectra of diffuse and planetary nebulae. He suggested that interferometer observations would help also in this work.

\title{
COMMISSION 29. (STELLAR SPECTRA.)
}

\section{PRESIDENT: Prof. H. N. Russeil. \\ SECRETARY: Dr P. Swings.}

I. Le rapport distribué aux personnes présentes commence par un court aperçu des principaux travaux faits dans le domaine des spectres stellaires depuis l'assemblée précédente. Le Président demande si l'une ou l'autre personne désire suggérer des modifications ou compléments à cet exposé. Aucune observation n'est présentée.

2. Le rapport du sous-comité chargé de l'examen des critères de classification des spectres stellaires est ensuite mis en discussion. Une lettre de Mme PayneGaposchkin a été reçue à ce sujet; Mme Payne-Gaposchkin signale que des détails manquent dans le rapport du sous-comité; elle demande aussi que soient définis clairement les types $A_{7}$ et $K_{7}$ actuellement utilisés fréquemment, ainsi que les symboles $g$ et $d$ distinguant les étoiles géantes et naines.

Pour ce qui concerne le premier point, le président du sous-comité, M. W. S. Adams, insiste sur le fait que le rapport n'a jamais eu la prétention d'être un exposé complet; il est en fait destiné aux personnes qui débutent dans ce domaine et non aux astronomes spécialisés. Pour ce qui concerne les autres points de la lettre de Mme Payne-Gaposchkin, M. Russell estime que cela peut constituer une partie de la tâche à continuer par le sous-comité.

Mlle Cannon demande ce qu'est devenu le projet de publier des reproductions de spectres stellaires typiques. M. Adams indique la difficulté d'une telle réalisation pour des raisons d'échelles; le sous-comité espère d'ailleurs s'occuper de la question.

A l'unanimité, le rapport est adopté et il est décidé que le sous-comité continuera le travail et se chargera notamment de l'illustrer éventuellement au moyen de reproductions de spectres typiques.

3. Rapport du sous-comité chargé de la classification des étoiles de Wolf-Rayet. En l'absence de M. C. S. Beals, Président de ce sous-comité, M. H. H. Plaskett présente le rapport et signale combien la rédaction en a été difficile; avec $\mathrm{Mme}$ Payne-Gaposchkin, il serait d'avis que les intensités totales des bandes d'émission seraient utiles pour la classification des étoiles de Wolf-Rayet; la même opinion est exprimée par Mme Payne-Gaposchkin dans une lettre au Président.

Le Président insiste sur le fait que la question n'a pu être réglée aisément à temps, à cause de la mort tragique de $\mathrm{M}$. Waterfield qui était chargé d'obtenir des spectres d'étoiles de Wolf-Rayet de l'hémisphère sud. Il propose que le rapport de MM. C. S. Beals et H. H. Plaskett soit joint comme appendice et que le travail soit continué.

M. Shapley signale que durant ces derniers mois, un certain nombre de spectres très utiles ont été obtenus par le successeur de $\mathrm{M}$. Waterfield.

Après un échange de vues auquel prennent part MM. Shapley, Adams, H. H. Plaskett, J. S. Plaskett et le Président, il est unanimement admis que le rapport sera publié en appendice, que Mme Payne-Gaposchkin sera invitée à joindre un second appendice contenant ses remarques et que le travail sera continué par le sous-comité. 
4. Le Président suggère qu'il soit constitué un sous-comité chargé de la classification des spectres de novae.

M. Abetti suggère que ce sous-comité s'occupe également des spectres présentant des raies d'intensité variable. M. Milne demande au Président de définir avec précision le rôle exact de ce sous-comité.

Le Président répond que le sous-comité en question s'occuperait, avant tout, des spectres des novae; par suite, il rentre bien dans le cadre de la commission 29 plutôt que dans les sections de photométrie ou de constitution des étoiles. D'autre part, ce sous-comité est en quelque sorte "occasionnel": on a pu tout récemment réunir un très grand nombre de spectres de Nova Herculis; dans l'Astrophysical Journal M. Struve a récemment suggéré avec raison qu'on réunisse toutes les listes de spectres obtenus de cette nova. Le Présidenteroit donc que le sous-comité devrait se limiter aux novae et n'envisager actuellement ni les étoiles à raies variables, ni les étoiles Be.

M. Milne suggère que ce sous-comité examine les relations entre novae et rayons cosmiques. Le Président trouve cette suggestion excellente; il est décidé qu'on demandera au sous-comité de se mettre éventuellement en liaison à ce sujet avec les instituts de physique de Cambridge, Chicago et Pasadena.

A l'unanimité le rapport de la commission est adopté dans son ensemble.

\section{COMMISSION 30. (RADIAL VELOCITIES.)}

\section{President: Dr J. S. Plaskett \\ SeCRETARY: Dr W. S. Adams.}

Section I of the Report was adopted without discussion save for the correction of a misprint.

The Report of the Sub-Committee on Standard Velocity Stars in Section 2 was discussed in some detail. The President read a letter from Dr Young urging the more systematic and frequent observation of such stars at different observatories. Dr Plaskett also referred to the desirability of the inclusion of more faint stars of early type, particularly of type A, in the recommended list.

Prof. Salet called attention to his investigations indicating the presence in the large Lick Observatory Catalogue of Radial Velocities of slight systematic differences between the values measured for stars near or far from opposition. It is important to learn whether such differences arise from the value of the constant of aberration or from flexure in the instruments employed. Prof. Salet expressed the desire that observers publish not only the mean values of the radial velocities but individual values, giving the dates and hour angles. Dr Beer supported this suggestion. Dr Plaskett stated that in view of the high cost of such detailed publication this plan might prove difficult to carry out, but suggested that the necessary data could always be obtained through writing to the observers concerned. The importance of the question raised by Dr Salet was recognized by the Commission.

The Report of the Sub-Committee on Standard Velocity Stars was then adopted.

The Report of the Sub-Committee on Wave-Lengths was then considered. The President read a letter from Dr Moore in which he stated that he did not feel that a system of wave-lengths can be recommended for late-type stars such as has proved so useful for early-type spectra. Effective wave-lengths for such spectra necessarily depend upon many factors such as dispersion slit-width, exposure time and develop- 